\title{
Short Communication: Efficacy of Parenteral Ceftiofur for Treatment of Systemically Mild Clinical Mastitis in Dairy Cattle
}

\author{
J. R. Wenz, ${ }^{1}$ F. B. Garry, ${ }^{1}$ J. E. Lombard, ${ }^{2}$ R. Elia, ${ }^{1}$ D. Prentice,${ }^{1}$ and R. P. Dinsmore ${ }^{1}$ \\ ${ }_{1}^{1}$ Integrated Livestock Management, Department of Clinical Sciences, Colorado State University, Fort Collins 80523 \\ ${ }^{2}$ USDA:APHIS:VS:CEAH, Fort Collins, CO 80526
}

\begin{abstract}
The objective of this study was to evaluate the effect of intramuscular (i.m.) ceftiofur ( $2.2 \mathrm{mg} / \mathrm{kg}$ ) on important outcomes of systemically mild clinical mastitis episodes in lactating dairy cattle. Cows with clinical mastitis were randomly assigned to a treatment group: pirlimycin intramammary (i.m.m.) $(\mathrm{n}=35)$, pirlimycin i.m.m. and ceftiofur i.m.m. ( $\mathrm{n}=36)$, cephapirin i.m.m. ( $n=40)$, cephapirin i.m. and ceftiofur i.m. $(n=33)$. Sixty-nine, 22, and 9\% of initial cultures were gramnegative, gram-positive, and mixed, respectively. Logistic regression analysis showed no significant associations between treatment groups and loss of quarter, recurrence, or culling. Mixed infections, positive milk culture at $7 \mathrm{~d}$ after leaving hospital pen, decreased rumen motility, and absence of udder firmness were associated with increased odds of mastitis recurrence. The results suggest that i.m. ceftiofur treatment has no beneficial effects on the outcome of systemically mild clinical mastitis.
\end{abstract}

(Key words: clinical mastitis, ceftiofur, therapy)

Abbreviation key: CULLED = culled due to mastitis episode, DRIED = quarter dried chemically or teat amputated due to mastitis episode, i.m. = intramuscular, i.m.m. = intramammary, REMAST $=$ retreated clinical mastitis episode, $\mathbf{R E C U R}=$ recurrent clinical mastitis episode in the same quarter.

Some dairy herds that have successfully controlled contagious mastitis pathogens and lowered their bulk tank somatic cell count have not decreased the incidence of clinical mastitis presumably due to an increase in mastitis caused by environmental pathogens. In many such herds, 25 to $60 \%$ of clinical mastitis is caused by coliform pathogens, primarily Escherichia coli (Shpigel et al., 1998; Hogan and Smith, 2003). Commercial

Received March 15, 2005.

Accepted June 24, 2005. edu. intramammary (i.m.m.) antibiotics available in the United States have limited activity against gram-negative mastitis organisms (Watts et al., 1995). Therefore, the immune response, primarily neutrophils in the mammary gland, is responsible for elimination of the gram-negative bacteria. There is increasing evidence that coliform bacteria can cause chronic IMI. Bradley and Green (2001) reported that $35 \%$ of clinical cases were due to $E$. coli and $24 \%$ of $E$. coli mastitis was due to recurrent clinical episodes in the same quarter. Genotype determination indicated $86 \%$ of recurrent episodes were due to persistent $E$. coli infections. Döpfer et al. (1999) reported $4.8 \%$ of all clinical mastitis was attributable to persistent $E$. coli IMI. Persistent coliform infection may be due to failure of the immune system to effect a bacteriologic cure of the mammary gland. Antibiotic intervention may assist the clearance of gram-negative bacteria from infected glands to improve outcomes of clinical mastitis episodes.

Intramuscular (i.m.) ceftiofur does not attain effective concentrations in the normal or inflamed mammary gland (Owens et al., 1990; Erskine et al., 1995) although treatment benefit in cows with severe coliform mastitis may occur from reduced negative effects of bacteremia (Erskine et al., 2002). Döpfer et al. (2001) showed that $E$. coli isolated from a chronically infected gland could penetrate epithelial cells. These data and the desire to reduce rates of recurrent clinical mastitis episodes have resulted in many producers and veterinarians treating mild gram-negative infections with i.m. ceftiofur.

The objectives of this study were to determine the effect of i.m. ceftiofur on rate of recurrent clinical mastitis episodes in the same quarter, culture-negative milk samples $7 \mathrm{~d}$ after leaving hospital pen, retreatment rate, and the incidence of mastitis episode-related loss of quarter, death, and culling in dairy cattle with systemically mild clinical mastitis.

The study was performed from June 2002 to September 2003 , on a commercial dairy that milked 1300 cows with an average bulk tank SCC of 200,000 cells/mL. The herd was vaccinated with a gram-negative, core antigen vaccine following label instructions plus an additional booster at 80 DIM. 
Table 1. Cows with mild clinical mastitis by treatment group and 0-h milk culture result.

\begin{tabular}{lllllll}
\hline $\begin{array}{l}\text { Treatment } \\
\text { group }\end{array}$ & $\begin{array}{l}\text { Total cows } \\
\text { with mild } \\
\text { mastitis }\end{array}$ & $\begin{array}{l}\text { Escherichia } \\
\text { coli }\end{array}$ & $\begin{array}{l}\text { Total } \\
\text { gram-negative }\end{array}$ & $\begin{array}{l}\text { Environmental } \\
\text { Streptococcus } \\
\text { spp. }\end{array}$ & $\begin{array}{l}\text { Total } \\
\text { gram-positive }\end{array}$ & Mixed $^{2}$ \\
\hline PIR & 35 & 21 & 26 & 2 & 3 & 6 \\
PIREX & 36 & 20 & 24 & 4 & 9 & 3 \\
CEF & 40 & 22 & 26 & 9 & 13 & 1 \\
CEFEX & 33 & 20 & 23 & 6 & 7 & 3 \\
Total & 144 & 83 & 99 & 21 & 32 & 13 \\
\hline
\end{tabular}

${ }^{1} \mathrm{PIR}=$ Pirlimycin intramammary; PIREX = pirlimycin intramammary, ceftiofur intramuscular; $\mathrm{CEF}=$ cephapirin intramammary; and CEFEX = cephapirin intramammary, ceftiofur intramuscular.

${ }^{2}$ Mixed = Mixed gram-negative and gram-positive milk culture result.

Lactating cows with systemically mild clinical mastitis and a positive 0 -h (initial) milk culture result were enrolled in the study. Systemic disease severity was defined as described previously (Wenz et al., 2001). Briefly, systemically mild clinical mastitis cases displayed local signs of inflammation (abnormal milk or gland, or both), with limited signs of systemic disease. Cows were excluded from the study if multiple glands were affected; they had been treated for clinical mastitis $30 \mathrm{~d}$ before enrollment; they had significant teat-end damage; or had concurrent clinical disease.

Cows were randomly assigned to 1 of 4 treatment groups: $50 \mathrm{mg}$ of pirlimycin, i.m.m. once a day for $2 \mathrm{~d}$ $(\mathrm{n}=35) ; 50 \mathrm{mg}$ of pirlimycin, i.m.m. once a day for $2 \mathrm{~d}$ and ceftiofur, once a day for $3 \mathrm{~d}(\mathrm{n}=36) ; 200 \mathrm{mg}$ of cephapirin, i.m.m. twice a day for $3 \mathrm{~d}(\mathrm{n}=40)$; and 200 $\mathrm{mg}$ of cephapirin, i.m.m. twice a day for $3 \mathrm{~d}$ and ceftiofur, once a day for $3 \mathrm{~d}(\mathrm{n}=33)$. Ceftiofur $(2.2 \mathrm{mg} / \mathrm{kg})$ was administered i.m. in the neck at no more than 10 $\mathrm{mL}$ per site.

Secretion from affected glands was collected at the 0$\mathrm{h}$ (initial) examination and $7 \mathrm{~d}$ after leaving the hospital pen. Samples were plated $(100 \mu \mathrm{L})$ and bacterial colonies were identified following National Mastitis Council guidelines (NMC, 1999) at 24 and $48 \mathrm{~h}$, and IMI diagnosed if samples contained $\geq 10 \mathrm{cfu} / \mathrm{mL}$ on both blood and MacConkey agar. Samples with $\geq 3$ different organisms were considered contaminated.

Cows had a retreatment (REMAST) recorded if, at the end of the assigned treatment, there was no im-

Table 2. Logistic regression model evaluating initial findings and treatment with mastitis recurrence in 144 cows with systemically mild clinical mastitis. ${ }^{1}$

\begin{tabular}{|c|c|c|c|c|c|c|}
\hline Parameter & Level & $\begin{array}{l}\text { Beta } \\
\text { coefficient }\end{array}$ & $\mathrm{SE}$ & $\begin{array}{l}\text { Odds } \\
\text { ratio }\end{array}$ & $\begin{array}{l}95 \% \text { Confidence } \\
\text { interval }\end{array}$ & $\begin{array}{l}\text { Wald } F \\
P \text {-value }\end{array}$ \\
\hline Intercept & & 0.0850 & 0.6221 & NA & & 0.8913 \\
\hline \multirow[t]{5}{*}{ Treatment $^{2}$} & & & & & & 0.6256 \\
\hline & PIR & & & Referent & & \\
\hline & PIREX & -0.9084 & 0.7402 & 0.4 & $0.1-1.7$ & \\
\hline & $\mathrm{CEF}$ & -0.3963 & 0.7134 & 0.7 & $0.2-2.7$ & \\
\hline & CEFEX & -0.1419 & 0.7702 & 0.9 & $0.2-3.9$ & \\
\hline \multirow[t]{4}{*}{ Gram stain } & & & & & & 0.0456 \\
\hline & Mixed & 1.2785 & 0.5145 & 7.7 & $1.4-43.4$ & \\
\hline & Negative & -0.5123 & 0.3786 & & $0.4-4.5$ & \\
\hline & Positive & & & Referent & & \\
\hline \multirow[t]{3}{*}{ Culture-negative } & & & & & & 0.0081 \\
\hline & No & 0.7257 & 0.2741 & & $1.5-12.5$ & \\
\hline & Yes & & & Referent & & \\
\hline \multirow[t]{3}{*}{ Rumen atony } & & & & & & 0.0066 \\
\hline & Yes & 0.8969 & 0.3301 & 6.0 & $1.6-21.9$ & \\
\hline & No & & & Referent & & \\
\hline \multirow[t]{2}{*}{ Udder firmness } & & & & & & 0.0158 \\
\hline & $\begin{array}{l}\text { No } \\
\text { Yes }\end{array}$ & 0.6936 & 0.2873 & $\begin{array}{l}4.0 \\
\text { Referent }\end{array}$ & $1.3-12.3$ & \\
\hline
\end{tabular}

${ }^{1}$ All bacterial isolates included.

${ }^{2} \mathrm{PIR}=$ Pirlimycin intramammary; PIREX = pirlimycin intramammary, ceftiofur intramuscular; CEF = cephapirin intramammary; and CEFEX = cephapirin intramammary, ceftiofur intramuscular. 
Table 3. Outcomes of cows with systemically mild clinical mastitis by $0 \mathrm{~h}$ culture result ${ }^{1}$ and treatment group. ${ }^{2}$

\begin{tabular}{|c|c|c|c|c|c|c|c|c|c|c|c|c|c|c|c|c|}
\hline \multirow[b]{3}{*}{ Outcome $^{3}$} & \multicolumn{8}{|c|}{ GN } & \multicolumn{8}{|c|}{ ALL } \\
\hline & \multicolumn{2}{|c|}{ PIR } & \multicolumn{2}{|c|}{ PIREX } & \multicolumn{2}{|c|}{$\mathrm{CEF}$} & \multicolumn{2}{|c|}{ CEFEX } & \multicolumn{2}{|c|}{ PIR } & \multicolumn{2}{|c|}{ PIREX } & \multicolumn{2}{|c|}{$\mathrm{CEF}$} & \multicolumn{2}{|c|}{ CEFEX } \\
\hline & No. ${ }^{4}$ & $\%$ & No. & $\%$ & No. & $\%$ & No. & $\%$ & No. & $\%$ & No. & $\%$ & No. & $\%$ & No. & $\%$ \\
\hline DRIED & $1 / 27$ & 3.7 & $3 / 24$ & 13 & $0 / 25$ & 0 & $2 / 23$ & 8.7 & $2 / 35$ & 5.7 & $5 / 36$ & 14 & $1 / 40$ & 2.5 & $2 / 33$ & 6.1 \\
\hline CULLED & $3 / 27$ & 11 & $1 / 24$ & 4.2 & $1 / 25$ & 4.0 & $0 / 23$ & 0 & $3 / 35$ & 8.6 & $1 / 36$ & 2.8 & $2 / 40$ & 5.0 & $2 / 33$ & 6.1 \\
\hline REMAST & $12 / 26$ & 46 & $7 / 23$ & 30 & $4 / 25$ & 16 & $10 / 23$ & 43 & $16 / 34$ & 47 & $13 / 35$ & 37 & $9 / 40$ & 23 & $11 / 33$ & 33 \\
\hline Cult. Neg. & $7 / 22$ & 32 & $11 / 22$ & 50 & $12 / 24$ & 50 & $9 / 21$ & 43 & $8 / 30$ & 27 & $14 / 31$ & 45 & $13 / 39$ & 33 & $15 / 29$ & 52 \\
\hline RECUR & $6 / 21$ & 29 & $1 / 16$ & 6.3 & $4 / 23$ & 17 & $5 / 21$ & 24 & $9 / 29$ & 31 & $5 / 27$ & 19 & 8/38 & 21 & $7 / 29$ & 24 \\
\hline
\end{tabular}

${ }^{1}$ Culture result: GN = gram-negative bacterial isolates; ALL = all bacterial isolates.

${ }^{2}$ Treatment groups: PIR = pirlimycin intramammary; PIREX = pirlimycin intramammary, ceftiofur intramuscular; CEF $=$ cephapirin intramammary; and CEFEX = cephapirin intramammary, ceftiofur intramuscular.

${ }^{3}$ Outcomes: DRIED = quarter dried chemically or teat amputated; CULLED = culled for mastitis or low milk production within $30 \mathrm{~d}$ of enrollment date; REMAST = retreatment of clinical mastitis episode was necessary; Cult. Neg. = culture-negative defined as no growth or growth different from $0 \mathrm{~h}$ on culture $7 \mathrm{~d}$ after leaving hospital pen; and RECUR = clinical mastitis episode in the same quarter 15 to $90 \mathrm{~d}$ after enrollment date.

${ }^{4}$ No.: Numerator $=$ number of cows with outcome, denominator $=$ total number of cows in treatment group available for evaluation.

provement or the milk was still abnormal $2 \mathrm{~d}$ after the last treatment and further antibiotic therapy was administered. A recurrent mastitis episode (RECUR) was recorded if mastitis was identified in the same quarter from 15 to $90 \mathrm{~d}$ after the initial episode. Milk samples were defined as culture-negative if there was no growth or growth different from the 0 -h sample on milk samples obtained $7 \mathrm{~d}$ after leaving the hospital pen. Loss of quarter (DRIED), death, and culling due to mastitis were assessed. No cows died during the clinical mastitis episodes. Cows leaving the herd as a direct result of mastitis were classified as culled (CULLED). The association of treatments and initial clinical findings with outcomes was evaluated with logistic regression using a stepwise backward elimination procedure (PROC LOGISTIC, SAS v. 9.01; SAS Institute, Inc., Cary, NC).

One hundred forty-four cows with systemically mild clinical mastitis were enrolled (Table 1). Gram-negative bacteria were the predominant isolates $(99 / 144 ; 68.8 \%)$ with $E$. coli the most common $(83 / 144 ; 57.6)$. There were fewer gram-positive isolates $(32 / 144 ; 22.2 \%)\left(\chi^{2}, P<\right.$ 0.001), with environmental Streptococcus spp. being the most common $(21 / 144 ; 14.6 \%)$. The mean incidence of clinical mastitis in the herd was 5.4 episodes (range of 4.8 to 7.3 episodes)/100 cows per mo during the study. Approximately $85 \%$ of all clinical mastitis and $95 \%$ of acute coliform mastitis in the herd was systemically mild.

Treatment was not significantly associated with RECUR (Wald F, $P=0.9$; Table 2). Significant variables in the final model included culture Gram stain, culturenegative $7 \mathrm{~d}$ after leaving the hospital pen, and presence of rumen atony and udder firmness (Table 2). Cows with mixed infection were 8.9 times more likely to RE-
CUR than those with gram-positive infection. Cows with culture-positive status $7 \mathrm{~d}$ post-hospital pen were 4.4 times more likely to RECUR. Cows with rumen atony or without udder firmness were 6.0 and 3.9 times more likely to RECUR, respectively. The association between RECUR and local as well as systemic disease signs is interesting and warrants further investigation. There was no association between treatment and DRIED or CULLED.

A comparison by treatment group for all bacterial isolates or gram-negative isolates alone showed no significant differences for the outcomes evaluated (Table $3)$. Intramuscular ceftiofur had no effect on the outcomes in this study. Low cow numbers per treatment group may have limited the power of the study; however, our results and prudent drug-use guidelines would suggest that i.m. ceftiofur not be used for treatment of systemically mild acute coliform mastitis.

\section{REFERENCES}

Bradley, A., and M. Green. 2001. Adaptation of Escherichia coli to the bovine mammary gland. J. Clin. Microbiol. 39:1845-1849.

Döpfer, D., H. W. Barkema, T. J. Lam, Y. H. Schukken, and W. Gaastra. 1999. Recurrent clinical mastitis caused by Escherichia coli in dairy cows. J. Dairy Sci. 82:80-85.

Döpfer, D., H. Nederbragt, R. A. Almeida, and W. Gaastra. 2001. Studies about the mechanism of internalization by mammary epithelial cells of Escherichia coli isolated from persistent bovine mastitis. Vet. Microbiol. 80:285-296.

Erskine, R. J., P. C. Bartlett, and J. L. VanLente. 2002. Efficacy of systemic ceftiofur as a therapy for severe clinical mastitis in dairy cattle. J. Dairy Sci. 85:2571-2575.

Erskine, R. J., R. C. Wilson, J. W. Tyler, K. A. McClure, R. S. Nelson, and H. J. Spears. 1995. Ceftiofur distribution in serum and milk from clinically normal cows and cows with experimental Escherichia coli-induced mastitis. JAVMA 56:481-485.

Hogan, J., and K. L. Smith. 2003. Coliform Mastitis. Vet. Res. 34:507-519. 
National Mastitis Council (NMC). 1999. Laboratory Handbook on Bovine Mastitis. NMC, Verona, WI.

Owens, W. E., Z. Y. Xiang, C. H. Ray, and S. C. Nickerson. 1990. Determination of milk and mammary tissue concentrations of ceftiofur after intramammary and intramuscular therapy. J. Dairy Sci. 73:3449-3456.

Shpigel, N. Y., M. Winkler, G. Ziv, and A. Saran. 1998. Clinical, bacteriological and epidemiological aspects of clinical mastitis in Israeli dairy herds. Prev. Vet. Med. 35:1-9.
Watts, J. L., S. A. Salmon, R. J. Yancey, S. C. Nickerson, L. J. Weaver, G. C. Holmberg, J. W. Pankey, and L. K. Fox. 1995. Antimicrobial susceptibility of microorganisms isolated from the mammary glands of dairy heifers. J. Dairy Sci. 78:1637-1648.

Wenz, J. R., G. M. Barrington, F. B. Garry, R. P. Dinsmore, and R. J. Callan. 2001. Use of systemic disease signs to assess disease severity in dairy cows with acute coliform mastitis. JAVMA 218:567-572. 